\title{
聞き手の態度が欺䐙性認知に及ぼす影響
}

\author{
品田 瑞穂 東京学芸大学
}

\section{The influence of an interviewer's attitude on the perceived deceptiveness of interviewees}

\author{
Mizuho Shinada (Tokyo Gakugei University)
}

\begin{abstract}
This study examined how the attitude of an interviewer affected the perceived deceptiveness of interviewees. Forty-four university students ( 20 males and 24 females) were interviewed, and either told the truth or lied about their experience. They were randomly assigned to the conversation condition or the accusation condition. The interviewer in the conversation condition nodded and made eye contact with the interviewees, whereas the interviewer in the accusation condition did not look at the interviewees and suspected what the interviewees said. Neutral observers watched the videotaped interviews and rated their perceived deceptiveness of the interviewees. The results indicated that accusations by the interviewer increased non-verbal behaviors (e.g., eye blinking) of the interviewees, and the increased eye blinking amplified the perceived deceptiveness of the interviewees.
\end{abstract}

Key words: perceived deceptiveness, non-verbal behavior, eye blinking.

The Japanese Journal of Psychology

2019, Vol. 89, No. 6, pp. 638-644

J-STAGE Advanced published date: November 15, 2018, doi.org/10.4992/jjpsy.89.17339

嘘は，規範的には善い行いとして認められないにも かかわらず，日常生活に深く根付いた行為である。あ る研究によると, 人は 1 日に少なくとも 1 回は嘘をつ くことが報告されている (DePaulo, Kashy, Kirkendol, Wyer, \& Epstein, 1996)。「嘘も方便」というょうに, 日常的な場面での嘘は，本当のことを言って相手を傷 つけたくないといった利他的な理由で生じ，人間関係 を円滑にする効果を持つことがある。しかし，嘘がよ り深刻な結果をもたらすこともある。例えば面接で応 募者が自分の経験について嘘をついており，面接官が その嘘を見抜けなかった場合には, 経験のある適切な 人材を採用することができなくなる。そのため, 面接 官にとっては応募者の発言の真偽を見極める必要があ る。

Correspondence concerning this article should be sent to: Mizuho Shinada, Department of Educational Psychology, Tokyo Gakugei University, NukuiKitamachi, Koganei 184-8501, Japan. (E-mail: shinada@u-gakugei.ac.jp)

本研究の一部は, 著者の指導のもとに実施された平成 28 年 度東京学芸大学卒業論文のための研究として行われた。また本 研究結果の一部は, 第 58 回日本社会心理学会大会 (2017) で発 表された。
それでは，他者が意図的に嘘をついていた場合，そ れを見抜くことはどの程度可能なのだろうか。虚偽検 出研究のメ夕分析に沶いては, 人が他者の嘘を見抜く 平均的な成功率は，チャンスレベルをわずかに上回る 程度（54\%）であることが報告されている（Bond \& DePaulo, 2006)。なぜ，他者の嘘を見抜くのはそれほ ど難しいのだろうか。これまでの研究では, 主な原因 として認知的バイアス, ヒューリスティックの使用, 個人差の無視といった嘘の聞き手側の要因が挙げられ てきた（Vrij, 2004）。その中でも，聞き手が妥当では ない手がかり（非言語的行動）を嘘のシグナルとして 判断に用いることが, 判断を誤らせる重要な要因とし て指摘されている。多くの人は，嘘をつくときには特 定の言語的・非言語的行動傾向が表れるという信念を 持っている (Strömwall, Granhag, \& Hartwig, 2004)。例 えば, 人は他者が嘘をついているか判断するときに, 身じろぎや瞬目といった不安や緊張に関連する視覚的 な手がかりを使う傾向がある (Anderson, DePaulo, Ansfield, Tickle, \& Green, 1999)。しかし, 実際にはこ うした手がかりは嘘とあまり関連しないため（大森・ 宮田, 1998; Vrij, Edward, Roberts, \& Bull, 2000), 手が かりを用いることによって嘘の検出はかえって難しく なるようである（Anderson et al., 1999）。 
以上の知見は，人々が妥当でない嘘の手がかりを使 う結果, 嘘についての判断が歪んでしまうことを示し ている。このことから, 話し手が不安や緊張に関連す る非言語的行動を示すほど，嘘の判断は歪みやすいと 考えられる。それでは，どのような状況において，そ うした手がかりが増加するのだろうか。これまでの二 者の会話場面に関する研究においては, 聞き手が厳し い態度をとった場合，好意的な態度をとった場合に比 較して, 話し手の瞬目が増えることが示されている(大 森, 2007)。このことから, 聞き手の㛜しい態度は, 嘘の手がかりとして解釈されやすい（実際には妥当な 手がかりではない）話し手の非言語的行動を増やし, 結果として嘘の判断を歪ませるのではないかと考えら れる。この予測と一貫する知見としては, 警察官と容 疑者の関係において，聞き手である警察官が綮しい態 度で容疑者に質問をすると，容疑者に対する false positive（嘘をついていないにもかかわらず，嘘だと 判断される割合)が増加することが示されている (Vrij, Mann, Kristen, \& Fisher, 2007)。したがって，聞き手の 態度が話し手に何らかの影響を及ぼし，結果として嘘 の判断が歪む可能性は十分に考えられる。しかし, こ のような一連のプロセスが実際に生じるのかどうかに 関しては，これまで実証的検討はなされていない。そ こで本研究は, 聞き手の態度が話し手の非言語的行動 に影響を与え, 結果として嘘の判断をより歪ませるの かを実験によって検討した。具体的には, 話し手を疑っ ているかのように厳しくインタビューを行う詰問条件 と，通常の会話と同じようにリラックスした雲囲気で インタビューを行う会話条件を設定した。話し手は自 分の経験について嘘をつく嘘条件と, 嘘をつかない本 当条件のいずれかに割り振られた。このインタビュー の様子を録画し, 話し手の部分のみを評定者に見せ， 話し手が嘘をついていると思う程度を，欺瞞性認知尺 度（村井, 1999）により評定を求めた。本研究で検討 した作業仮説は以下の 3 つである。

仮説 1 詰問条件では, 会話条件に比較して, 話し 手の不安感は高く, 瞬目が多い。

仮説 2 話し手の瞬目が多いほど，嘘をついている と思われやすい。

仮説 3 話し手が嘘をついているかどうかにかかわ らず，詰問条件では会話条件に比較して，話し手は嘘 をついていると思われやすい。

\section{方 法}

実験参加者 44 名の日本人の大学生（男性 20 名, 女性 24 名，平均年齢 19.68 歳）が実験に参加した。

実験デザイン 聞き手の態度（詰問・会話） ×発話 内容 (本当・嘘) の参加者間要因配置とした。

手続き 本研究では, 実験参加者に発話内容を指示 する説明担当者と，インタビューを担当する聞き手の
2 人が実験を実施した。説明担当者と聞き手はともに 心理学を専攻する大学生であり, 実験の目的と仮説に ついて知らされた上で, すべてのセッションを通して 同じ役割で実験を実施した。聞き手の態度を統制する ため，聞き手は話し手が本当・嘘のいずれの条件に割 り振られたか知らされないままインタビューを行っ た。説明担当者は，実験参加者との予定調整を行う際 に，参加者のこれまでのアルバイト経験について尋ね た。

実験参加者が到着後，説明担当者がまず実験の概要 について説明した。具体的には実験は事前質問紙，発 話課題 (インタビュー), 事後質問紙の順に行うこと, 発話内容の分析を後日行うため発話課題をビデオ撮影 すること，データの保管と破衰，実験参加者同意書に ついて説明し，署名を求めた。次に説明担当者は 20 種類の部活動を提示し, 実験参加者になじみのない部 活を 3 つ選択するよう求めた。続いて，事前質問紙を 渡して回答を求めた。その後, 発話課題の詳しい内容 について説明した。具体的には, 発話課題では後から やってくる別の担当者がアルバイトまたは部活動につ いて尋ねること，発話課題の担当者（聞き手）は実験 参加者の表情や態度から，実験参加者の話が本当か嘘 かを判断することを説明した。この後，説明担当者は 実験参加者についての情報（アルバイトと部活動）に ついてのメモを残して，聞き手と入れ替わった。この ときのメモには，本当条件では実験参加者に関する正 しい情報が記載され, 嘘条件では実験参加者が経験し たことがないアルバイトと部活動の情報が記載されて いた。なお，メモは実験参加者には見せず，内容も説 明しなかった。入室した聞き手は，実験参加者の上半 身（胸から上）が撮影できるよう設定したビデオカメ ラで録画を開始した後，メモを読みながら部活動とア ルバイトについて質問した。質問内容は，部活（アル バイト）を選んだ理由, 部活の中で楽しかった・大変 だった出来事・学んだこと，アルバイトの長所・短所・ 困ったエピソード・心がけていることであった。質問 の内容と順序はすべてのセッションで同一であった。 約 5 分の会話実験の終了後, 録画を停止し, 事後質問 紙を実施した。最後にデブリーフィングを行い，謝礼 を渡して実験を終了した。

発話内容 (本当・嘘) の操作 両条件において, 実 験担当者は，実験参加者の話している内容が本当か嘘 かは知らないと教示した。その上で, 本当条件の参加 者には，「自分の話が本当だと信じてもらえるように， できる限り信憑性があるように」話すよう教示した。 嘘条件では，「話している内容が嘘だと思われないよ うに」話すよう教示した。また嘘条件では，会話実験 の担当者は，これまでの実験参加者のアルバイトや部 活動について，事実と異なることを質問する（例えば 参加者が野球部であれば，「吹奏楽部でしたね？」な 
どと尋ねる）ので，それに沿うように回答するよう教 示した。

聞き手の態度の操作 詰問条件の聞き手は, 目を合 わせる，相桘を打つといった好意的な言動を示さな かった。さらに参加者が質問に答えた後に,「それは 本当ですか?」と聞き, 実験参加者に対して疑いを示 した。一方, 会話条件では相槌を打ちアイコンタクト をとるなど，通常の会話と同じようにふるまった。ま た詰問条件の聞き手は「面接官」としてフォーマルな 服装で現れ，会話条件では「担当者」として普段着で 現れた。

質問紙の構成 事前質問紙では，状態-特性不安尺 度 (State-Trait Anxiety Inventory: STAI; Spielberger, Gorsuch, \& Lushene, 1970）によって会話実験前の状態 不安を測定した。項目は, 遠山・千葉・末広 (1976) の翻訳による 4 件法の 20 項目を用いた。事後質問紙 においては，同じ 20 項目について，「実験中のあなた の状態にどれくらい当てはまりますか」というリード 文を用いて, 会話実験中の不安感について尋ねた。本 研究では先行研究（岩本他, 1989）の因子分析結果に 基づき,「気持ちが落ち着いている (逆転項目)」,「ピ リピリと気持ちが張り詰めている」などの項目からな る9項目を「現在の不安感」として用いた。なお，こ の尺度には「緊張している」などの項目からなる「現 在の緊張感」因子も想定されていたが, 実験前後とも に信頼性係数が低かったため $(\alpha<.67)$, 分析には用 いていない。また，個人差の統制を目的として嘘への 慣れ等を測定する尺度（朴・大坊, 2014）を含めたが, 条件抒よび主要な変数との関連はなかったため, 以下 の分析では省略する。この他に操作チェック項目とし て, 実験中の不安に関する項目（「実験者が自分の話 を信じているか不安に思った」), 嘘に関する項目（「嘘 がばれるのではないかと不安に思った」)，実験者の詰 問的な態度についての項目（「実験者は自分のことを 疑っていると思った」), 発話への意欲に関する 1 項目 (「実験者に自分の話を信じさせようと思った」)，実験 者の好意的態度に関する 3 項目（「実験者は自分の話 に興味があると思った」，「実験者は自分の話を親身に 聞いてくれると思った」，「実験者は目を見て話を聞い てくれた」)の計 7 項目を作成した (いずれも 5 件法)。

欺瞞性認知の測定 44 名分の録画映像について, 回答の長さが打拉むね同じであった「○○部ならでは の楽しかった出来事について教えてください」という 質問の後の 1 分間を抜き出し, 聞き手の声を除いたビ デオを作成した。この質問は, インタビューの前半(す べての質問の中で 2 番目, インタビュー開始から約 1 分経過した時点）に尋ねられた。これらを実験参加者 と面識のない大学生（女性）2名の評定者が見て, 欺 瞞性認知尺度（村井, 1999）に回答した。その際真実 バイアスの影響を除くため, 評定前に, 44 名のうち
半数は本当のことを言っており，半数は嘘をついてい ると説明した。また欺瞞度尺度は,「本当っぽい一嘘っ ぽい」,「誠実な一不誠実な」,「信用できる一信用でき ない」,「正直な一不正直な」,「何も隠していないよう な一何か隠しているような」の 5 項目からなる 7 件法 の尺度であるが，このうち「誠実な一不誠実な」に関 しては，発話内容というより人格に関わる形容詞であ るため判断できなかったと評定者から指摘されたた め, 分析から除いた。評定者間の欺盿性認知得点の順 位相関係数は中程度 $(\rho=.28, p=.07)$ であったため, 評定得点の平均を欺瞞性認知得点として用いた $(M=$ $3.51, S D=1.42)$ 。なお, 欺瞞性認知尺度の信頼性係数 は $\alpha=.96$ であった。

瞬目の測定 欺瞞性認知の評定者とは別の大学院生 2 名（女性）が, 欺瞞性認知の測定に用いられたビデ オと同じ 1 分間のビデオを見て, 瞬目の頻度を測定し た。2名のコーダーによる測定值間の相関係数は十分 に高かったため $(r=.95)$, 平均值を瞬目回数とした $(M$ $=34.15, S D=14.37$ )。

\section{結 果}

予備分析 分析はSAS（ver 9.4）を用いて行った。 本研究では, 聞き手と話し手の間の相互作用が与える 影響を検討するため, 聞き手の態度を操作した。この 操作の妥当性を検討するために,「実験者（聞き手） は自分のことを疑っていると思った」程度（5 件法） について, 条件（聞き手の態度 $\times$ 発話内容）を独立変 数とした 2 要因分散分析を行った。その結果について, 聞き手の態度の主効果 $(F(1,43)=16.45, p<.01)$ が みられた。発話内容の真偽の主効果 $(F(1,43)=3.40$, $p<.10)$ は有意傾向であり, 交互作用効果はみられ なかった $(F(1,43)=0.14, n s)$ 。すなわち, 嘘条件に 扔いても（詰問条件 : $M=3.91, S D=1.14$; 会話条件 : $M=2.27, S D=1.10)$, 本当条件に扔いても（詰問条件： $M=3.09, S D=1.45$; 会話条件 : $M=1.73, S D=1.19)$, 詰問条件の実験参加者は, 会話条件に比べて, 聞き手 に疑われているのではないかと感じていた。また紙幅 の都合上詳細を省くが，好意的態度に関する 3 項目の 平均值はいずれも会話条件において詰問条件よりも有 意に高かった（聞き手の態度の主効果 $F \mathrm{~s}>6.73 ） 。 以 ~$ 上より, 実験参加者の反応はいずれも実験操作と一貫 しており, 操作の妥当性が確認された。

聞き手の態度による影響 分析はSAS（ver 9.4）を 用いて行った。Table 1 に本研究の主要な変数の条件 ごとの平均值と標準偏差を示す。本研究では, 聞き手 が話し手を厳しく問い詰めることによって, 話し手に 不安や緊張が生じ, 嘘の手がかりとして用いられやす い非言語的手がかり（瞬目）が増加すると予測した。 この予測を検討するため, 詰問条件では, 会話条件に 比較して, 話し手の不安感抒よび瞬目が多いという仮 
Table 1

条件ごとの主要な変数の平均值（括弧内は標準偏差）

\begin{tabular}{llllll}
\hline & & \multicolumn{4}{c}{ 話し手の発話内容 } \\
\cline { 3 - 6 } 変数 & 聞き手の態度 & \multicolumn{2}{c}{ 本当条件 } & \multicolumn{3}{c}{ 嘘条件 } \\
\hline 欺瞞性認知 & 会話条件 & 2.94 & $(1.20)$ & 3.68 & $(1.40)$ \\
& 詰問条件 & 3.18 & $(1.61)$ & 4.25 & $(1.27)$ \\
\hline 不安感 (変化量) & 会話条件 & 0.09 & $(0.79)$ & 0.72 & $(0.37)$ \\
& 詰問条件 & 0.77 & $(0.35)$ & 0.81 & $(0.74)$ \\
\hline \multirow{2}{*}{ 瞬目回数 } & 会話条件 & 32.05 & $(12.09)$ & 28.00 & $(10.09)$ \\
& 詰問条件 & 38.95 & $(14.25)$ & 37.59 & $(18.77)$ \\
\hline
\end{tabular}

説 1 を立てた。仮説を検討するため, 実験中の不安感 （実験後に測定）から事前の不安感を差し引いた不安 感の変化量を従属変数, 聞き手の態度と発話内容を独 立変数とした $2 \times 2$ の分散分析を行ったところ，聞き 手の態度の主効果 $(F(1,43)=4.53, p<.05)$ が有意 であり, 発話内容の主効果が有意傾向であった $(F(1$, $43)=3.42, p<.1)$ 。交互作用効果はみられなかった $(F$ $(1,43)=2.64, n s)$ 。したがって, 厳しく質問された場 合に, 話し手の不安感は増したと言える。この結果は, 仮説 1 と一貫している。

次に, 瞬目回数を従属変数として, 同様の 2 要因分 散分析を行った。その結果, 聞き手の態度の主効果が 有意傾向であり $(F(1,43)=3.73, p<.10)$, その他の 効果はなかった $(F \mathrm{~S}<0.41)$ 。したがって, 会話条件 に比較して詰問条件では話し手の瞬目回数はやや多い 傾向にあったが, 発話内容の真偽とは無関連であった。 以上より, 仮説 1 と一貫して, 詰問条件では会話条件 よりも不安が高まり, 瞬目が増加する傾向にあるとい う結果が示された。ただし瞬目に関しては条件の効果 は有意傾向にとどまったため, 仮説 1 は部分的に支持 された。なお，不安感の変化量と瞬目の間には関連は みられなかった $(r=-.09, n s)$ 。

欺瞞性認知に影響する要因 本研究では, 話し手に 対する欺鿃性認知，すなわち話し手が嘘をついている と思われる程度は, 話し手の瞬目が多いほど強まる(仮 説 2) と予測した。この予測は，一般に瞬目の多さが 嘘の手がかりとして用いられやすいことに基づいてい る。また，会話条件に比較して詰問条件では瞬目が増 えるため, 話し手が実際に嘘をついているかどうかに かかわらず，詰問条件では話し手が嘘をついていると 思われやすい（仮説 3）と予測した。まず仮説 2 を検 討するため, 瞬目回数と欺瞞性認知得点との相関関係 をみたところ，有意な正の相関係数が得られた $(r=$ $.31, p<.05)$ 。この結果は仮説 2 と一貫している。次に, 欺瞞性認知得点を従属変数, 条件（聞き手の態度 $\times$ 発 話内容）を独立変数とした 2 要因分散分析を行ったと ころ, 発話内容の主効果のみが有意であり $(F(1,43)$
$=4.72, p<.05)$, 聞き手の態度の主効果 $(F(1,43)=$ $0.94, n s)$ 抢よび交互作用効果 $(F(1,43)=0.16, n s)$ はみられなかった。したがって, 話し手が嘘をついて いる場合，本当のことを話している場合よりも，話し 手に対する欺瞞性認知が高まると言える。しかし仮説 3 に反し, 聞き手の態度は欺瞞性認知に影響を及ぼし ていなかった。

影響過程モデルの検討 本研究は, 判断者の持つ嘘 の手がかりに関する信念と, 会話における相互作用が, 嘘の判断に与える影響を包括的に検討することを目的 としている。これまでの分析から, 聞き手の態度によっ て話し手に対する欺瞞性認知が高まるという結果は得 られなかった。しかし, 詰問条件では話し手の瞬目が 会話条件よりも多く, また瞬目回数と欺瞞性認知に正 の関連があったことから，瞬目を媒介して聞き手の態 度が欺瞞性認知に影響を及ぼした可能性が考えられ る。

これらの影響過程を包括的に検討するため, Amos 21.0 を用いて最尤推定法による共分散構造分析を行っ た（Figure 1, 図中の数值は標準化係数を示す)。モデ ル全体の適合度は, $\mathrm{GFI}=.98, \mathrm{AGFI}=.95, \mathrm{CFI}=1.00$, RMSEA = .00 であった。また, 聞き手の態度が話し手 の瞬目回数を媒介して欺瞞性認知に与える間接効果に ついて，ブートストラップ法（反復 10,000 回）を用 いて分析を行ったところ, 間接効果 $(b=0.10, p<$ $.05,95 \% \mathrm{CI}[.00, .28])$ が有意であった。この結果から, 聞き手の厳しい態度は話し手の瞬目回数を増やし, 瞬 目回数が欺瞞性認知を高めるという影響過程が示され た。この影響は発話内容を統制した上でみられたこと から，たとえ本当のことを話していたとしても，聞き 手が厳しい態度をとると話し手の瞬目回数は増え, 話 し手の瞬目回数が多いと嘘をついているとみられやす くなると言える。

\section{考察}

本研究では, 嘘についての判断が歪む要因として, 聞き手が話し手に与える影響と，判断者が持つ嘘の手 
がかりについての信念に着目した。先行研究において, 聞き手が話し手を疑ってかかり，厳しく問い詰めるこ とによって，話し手が本当のことを話していたとして も，嘘をついていると思われやすくなることが示され ている（Vrij et al., 2007）。本研究はこれをふまえ，聞 き手の厳しい態度は話し手の非言語的行動（瞬目）を 増加させ, 結果として話し手に対する欺瞞性認知を高 めるという一連のプロセスについて検討を行った。こ のプロセスを検討するため, 聞き手の話し手に対する 態度を操作して実験を行い, 詰問条件では, 会話条件 に比較して, 話し手の不安感抒よび瞬目が多い（仮説 1)，話し手の瞬目が多いほど，嘘をついていると思わ れやすい（仮説 2)，話し手が嘘をついているかどう かにかかわらず，詰問条件では会話条件に比較して， 話し手は嘘をついていると思われやすい（仮説 3）と いう 3 つの仮説を検討した。その結果, 仮説 1 に関し ては部分的に支持され，仮説 2 は支持された。一方， 仮説 3 は支持されなかった。しかし, 影響過程モデル の分析結果から, 聞き手の態度は瞬目回数を媒介して 欺瞞性認知に間接効果を持つことが示された。つまり, 聞き手が厳しい態度をとるほうが話し手の瞬目回数は 多く, 瞬目回数が多いほど話し手に対する疑わしさは 強まるという関係がみられた。

先行研究においては, 聞き手の態度によって, 話し 手が嘘をついているという疑い（false positive）は有 意に高まった（Vrij et al., 2007）。これに対して本研究 では, 聞き手の影響は示されなかった。この原因とし ては, 先行研究では聞き手が現役の男性警察官であっ たため, 話し手に緊張や不安を与える効果は本研究よ りも格段に大きかったと考えられる。また, 先行研究
では嘘の判断を行う際，二者の会話の全体を見せてい る。このため,「聞き手がこれだけ疑っているのだから， 相手は嘘をついているのだろう」と判断者が考え, 話 し手が嘘をついていると思われやすくなった可能性も ある。さらに先行研究では, 他人のお金を盗んだと疑 われる状況を設定していた。実験参加者である一般的 な大学生にとって, 警察官に犯罪者だと疑われて詰問 される状況は稀であるため, 表出する反応も本研究よ り大きかったと考えられる。まとめると, 本研究では 先行研究に比較すると日常的な場面を設定したため, 聞き手が話し手に与える影響は相対的に弱かったと考 えられる。しかし逆の見方をすれば，本研究の結果か らは, 聞き手の影響力が相対的に弱い状況であっても, 話し手に対して影響を及ぼすことが示されたと言え る。このことから，嘘をついているかどうかを疑って いたとしても，そのことを相手に直接伝えたり，厳し く問い詰めたりするのは得策ではないことが示唆され る。相手が疑わしく見えたとしても，それが嘘をつい ているからなのか, それとも疑われたせいなのかが判 別しにくくなるからである。

また, 本研究では実験前後の不安感の変化量と, 瞬 目および欺瞞性認知との間に関連がみられなかった。 一般に, 不安なときには瞬目回数が増える傾向がある (Harrigan \& O’Connell, 1996)。したがって, 詰問条件 では会話条件に比較し，不安感が高まったため瞬目が 増加することも考えられたが, 不安感と瞬目回数との 間には関連はみられなかった。この理由としては, 本 研究では実験中の不安感を事後質問紙において振り 返って測定したのに対し, 欺瞞性認知の判断には実験 中の 1 分間を用いたことから，その 1 分間に感じた不

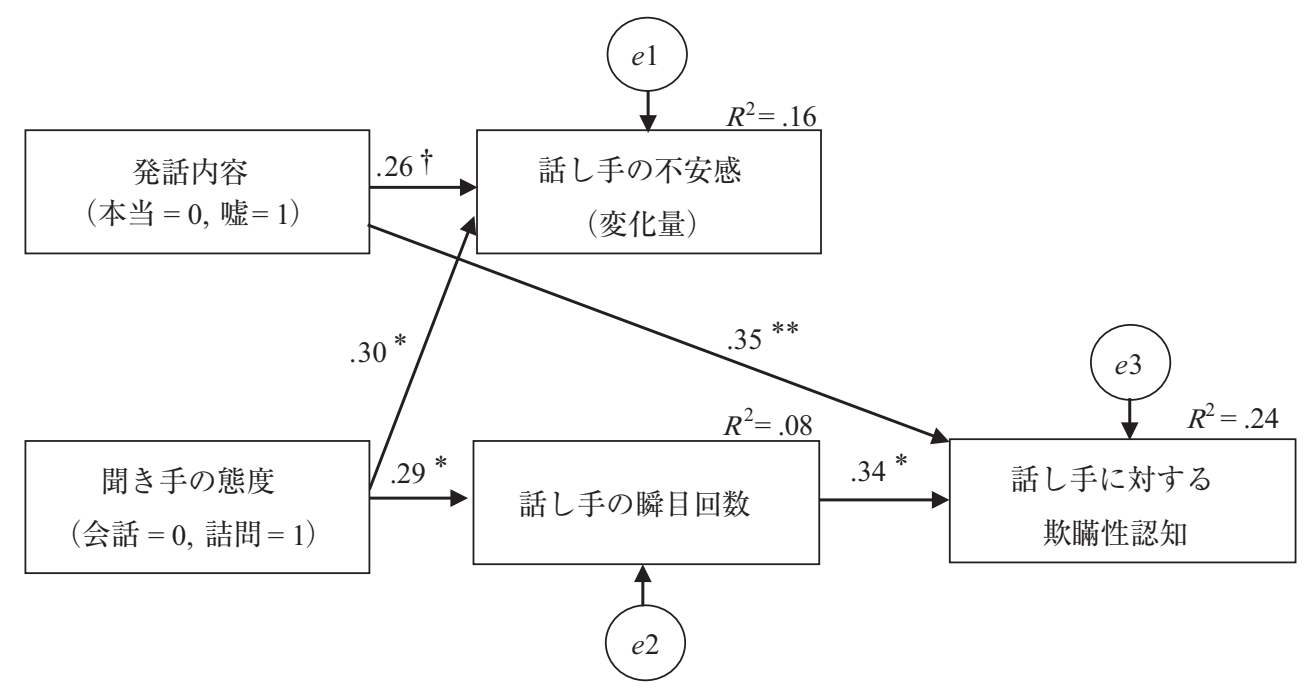

Figure 1. 欺瞞性認知への影響過程モデル。 $\dagger p<.10,{ }^{*} p<.05, * * p<.01$ 
安感と, 実験中に感じた不安感全体との間にずれが あった可能性が挙げられる。今後の研究においては, 参加者自身に実験後に動画を見てもらい，時系列に 沿ってそのときの不安感を思い出してもらうといった 方法が考えられる。また，自己報告による不安感と瞬 目に関連がみられない場合もあることから（稲垣（藤 井) ・伊藤, 2017），潜在的指標を用いた影響過程の検 討も有用であると考えられる。

また，本研究には手続き上のいくつかの問題点が残 されている。1点目は, 条件操作に関する問題である。 本研究の実験参加者は仮説や目的について知らされな かったが, 実験実施者は仮説について知らされていた。 実験者の行動はマニュアル化されていたが, 詰問条件 においては，話し手に対して厳しい態度をとるだけで なく，より不安を高めるような言動を無意識にとった 可能性は排除できない。このため, 本研究における仮 説 1 の解釈に関しては留意が必要である。また，本当 条件と嘘条件では，実験参加者に課題がわかりやすく なるよう説明の表現を変えたが，同一の教示を用いて も操作は可能であったため, 統制に厳密さが久けてい た可能性がある。第 3 に, 本研究で用いた欺瞞性認知 尺度得点には評定者による個人差が大きく，平均得点 として用いるには問題があった可能性がある。欺瞞性 認知に個人特性が及ぼす影響に関しては，これまでほ とんど研究されていないが (村井, 2005), 今後の研 究においては判断者側の要因を考慮することが必要だ と考えられる。

本研究の意義と今後の展望 本研究の聞き手は訓練 された心理学専攻の学生であり, マニュアル通りに実 験参加者とコミュニケーションをとった。この操作は, 聞き手の言動を統制するために行った。ただし，実際 の二者のコミュニケーション場面において，相手が嘘 をついていると思ったときには，本研究で設定した聞 き手とは異なる態度をとる可能性がある。例えば，先 行研究（Kassin, Goldstein, \& Savitsky, 2003）によれば, 相手が高確率で嘘をついていると信じた実験参加者 は，相手に対する疑いを露わにし，嘘をついていると 認めさせようと圧力をかけていた。このような直接的 な態度は, 話し手により強い緊張感や不安を与え, 瞬 目などの非言語的手がかりを誘発するだろう。した がって，聞き手が話し手に対して疑いを持つことで, 意図せずして話し手が疑わしく見える反応を引き出し てしまう可能性がある。こうした予言の自己成就的な 現象が生じると，いったん疑いをかけられた者がそれ に抗うのは非常に困難になるだろう。ただし，このよ うな一連のプロセスが実際に成立するかどうかに関し ては, 実証的検討が必要である。また, 本研究では瞬 目が嘘の手がかりとして誤って用いられるため欺瞞性 認知が増加すると予測したが, その他の理由も考えら れる。一般に, 瞬目の多い話し手は, 瞬目の少ない話
し手に比較して否定的な評価を受ける傾向がある（大 森・山田・宮田，1997）。したがって，瞬目が嘘の手 がかりとして用いられたため欺瞞性認知が高まったの ではなく，全体としての否定的な印象が欺瞞性認知に も波及したとも解釈できる。この点を切り分けるには, 判断者が持つ嘘の手がかりに関する信念を操作すると いった手続きが必要となる。

本研究は，嘘の判断を歪める要因として，聞き手が 与える影響と, 判断者の持つ嘘の手がかりに関する信


妥当性の低い嘘の手がかりに依存しないことに加え, 自己の与える影響に気づくことの重要性が示唆され る。対応バイアスが広くみられるように，私たちが他 者の行動を判断するときには，基本的には他者の内部 にその原因があると考える傾向がある。それはつまり， 自分自身が他者に与える影響についてはしばしば無自 覚であることを示唆する。本研究で得られた知見に基 づけば，他者が疑わしい反応を見せるのは，嘘をつい ているからだと考えがちである。しかし，その反応は 自分が他者に対して疑いの目を向けたために生じたも のかもしれない。このような気づきを持つことで，嘘 の判断に生じる歪みを低減することができるだろう。

\section{引用文献}

Anderson, D. E., DePaulo, B. M., Ansfield, M. E., Tickle, J. J., \& Green, E. (1999). Beliefs about cues to deception: Mindless stereotypes or untapped wisdom? Journal of Nonverbal Behavior, 23, 67-88.

Bond, C. F. Jr., \& DePaulo, B. M. (2006). Accuracy of deception judgments. Personality and Social Psychology Review, 10, 214-234.

DePaulo, B. M., Kashy, D. A., Kirkendol, S. E., Wyer, M. M., \& Epstein, J. A. (1996). Lying in everyday life. Journal of Personality and Social Psychology, 70, 979-995.

Harrigan, J. A., \& O’Connell, D. M. (1996). Facial Movements during anxiety states. Personality and Individual Differences, 21, 205-212.

稲垣 (藤井) 勉 ·伊藤忠弘 (2017). Implicit Association Test を用いた不安の測定と行動予測 長崎大学大 学教育イノベーションセンター紀要, 8,1-16.

岩本 美江子 · 百々 栄徳 · 米田 純子 · 石居房子 · 後藤 博 ·上田 洋一・森江 堯子 (1989). 状態-特性不 安尺度（STAI）の検討およびその騒音ストレス への応用に関する研究 日本衛生学雑誌, 43, 1116-1123.

Kassin, S. M., Goldstein, C. J., \& Savitsky, K. (2003). Behavioral confirmation in the interrogation room: On the dangers of presuming guilt. Law and Human Behavior, 27, 187-203.

村井 潤一郎 (1999)。恋愛関係において発言内容の好 意性が欺瞞性の認知に及ぼす影響 心理学研究, 70, 421-426. 
村井潤一郎 (2005)。強調語が発言内容の欺瞞性認知 に及ぼす影響 パーソナリティ研究，14,92-100.

大森慈子 (2007)。面接者の態度が被面接者の瞬目と 心拍に与える影響 仁愛大学研究紀要, 6, 31-39.

大森慈子・宮田洋 (1998). 心理学における瞬目研究 の新しい試み人文論究, 47,67-78.

大森慈子 - 山田冨美雄 - 宮田 洋 (1997). 対人認知 における瞬目の影響 社会心理学研究, 12,183189.

朴喜静・大坊郁夫 (2014). 個人特性が嘘をつくとき に表われる非言語行動に及ぼす影響 応用心理学 研究, 39, 215-224.

Spielberger, C. D., Gorsuch, R. L., \& Lushene. R. E. (1970). Manual for the State-Trait Anxiety Inventory. Palo Alto, CA: Consulting Psychologists Press.

Strömwall, L. A., Granhag, P. A., \& Hartwig, M. (2004). Practitioners' beliefs about deception. In P. A. Granhag \& L. Strömwall (Eds.), The detection of deception in fo- rensic contexts (pp. 229-250). New York: Cambridge University Press.

遠山 尚孝・千葉 良雄・末広 晃二（1976）。不安感情特性尺度（STAI）に関する研究 日本心理学会 第 40 回大会発表論文集, 891-892.

Vrij, A. (2004). Why professionals fail to catch liars and how they can improve. Legal and Criminological Psychology, 9, 159-181.

Vrij, A., Edward, K., Roberts, K., \& Bull, R. (2000). Detecting deceit via analysis of verbal and nonverbal behavior. Journal of Nonverbal Behavior, 24, 239-263.

Vrij, A., Mann, S., Kristen, S., \& Fisher, R. P. (2007). Cues to deception and ability to detect lies as a function of police interview styles. Law and Human Behavior, 31, $499-518$

2018. 2.22 受稿, 2018. 7.7 受理 